\title{
Validitas dan Praktikalitas E-Modul Berbasis Inkuiri Terbimbing Terintegrasi Laboratorium Virtual pada Materi Hidrolisis Garam kelas XI SMA/MA
}

\author{
Fadhillah ${ }^{1)}$ Andromeda ${ }^{1)^{*}}$ \\ ${ }^{1)}$ Prodi Pendidikan Kimia, FMIPA, Universitas Negeri Padang \\ Keterangan Penulis ${ }^{2)}$ \\ *andromedasaidir@yahoo.com
}

\begin{abstract}
This study aims to produce a salt hydrolysis e-module which is based on guided inquiry learning model and integrated with virtual laboratories and reveal the validity and practicality of e-modules. The type of this research is Reasearch and Development $(R \& D)$, the method used in this research is development model by using 4-D design. They are define, design, develop and disseminate. This research was limited to the stage of development, the validity and practicality test. The data collection instrument were observation, validity and practicality questionnaires. The e-module was validated by 6 experts, consisting of 3 chemistry lectures of FMIPA UNP and 3 chemistry teachers while test was carried out by 2 chemistry teachers and 15 XII grade students of MIPA SMAS Adabiah 2 Padang. Data form validity and practicality test were analyzed using Aiken's $V$ technique. Based on the results of the study, it was found that average Aiken's $V$ index $(V)$ of validity test was 0,83 with high validity category, the average Aiken's $V$ index $(V)$ of teachers practicality test was 0,81 with high practicality category and the average Aiken's $V$ index $(V)$ of students practicality was 0,82 with high practicality category. The results of the analysis of students answer on e-modules were obtained on average $90 \%$ on key questions, $94.8 \%$ on worksheets and $90 \%$ on evaluation sheets. Based on the results of the study it can be concluded that e-modules based on guided inquiry learning model and integrated with virtual laboratories on salt hydrolysis topic was valid and practical for chemistry learning in high school.
\end{abstract}

Keywords : E-Module, Guided Inquiry Learning, Virtual Laboratory, Salt Hydrolysis, Research and Development $(R \& D)$

This is an open access article distributed under the Creative Commons 4.0 Attribution License, which permits unrestricted use, distribution, and reproduction in any medium, provided the original work is properly cited. $\odot 2018$ by author and Universitas Negeri Padang.

\section{PENDAHULUAN}

Penyebaran COVID-19 sebagai pandemi global berdasarkan siaran pers World Health Organization (WHO) tahun 2020 telah mempengaruhi berbagai aspek dalam kehidupan manusia, salah satunya yaitu pada bidang pendidikan. Berdasarkan surat edaran kemendikbud nomor 4 tahun 2020 pada situs kemendikbud.go.id proses pembelajaran dilaksanakan secara daring/jarak jauh dirumah siswa masingmasing. Berdasarkan hal tersebut inovasi dalam bidang pendidikan sangat dibutuhkan dalam menunjang proses pembelajaran siswa. Inovasi yang dapat dilakukan yaitu dengan meningkatkan bahan ajar yang digunakan, salah satunya pengembangan bahan ajar dalam bentuk elektronik seperti modul elektronik atau e-modul.

E-modul yang memuat audio, video, animasi dan navigasi merupakan bentuk implementasi sumber belajar siswa secara mandiri sehingga dapat meningkatkan kompetensi dan pemahaman siswa yang ditampilkan dalam format elektronik
(Sugianto, dkk., 2013). E-modul dapat mendorong siswa untuk meningkatkan rasa percaya diri untuk ikut berperan aktif, serta berani dan percaya diri dalam menyampaikan pendapat dalam proses pembelajaran (Budiarti, dkk., 2016).

Kurikulum 2013 menuntut proses pembelajaran dilakukan dengan pendekatan saintifik dan berpusat pada siswa (student centered). Salah satu model pembelajaran yang sesuai dengan tuntutan Kurikulum 2013 tersebut adalah model pembelajaran inkuiri terbimbing. Model pembelajaran inkuiri terbimbing terdiri atas lima siklus/tahap yaitu orientasi, eksplorasi, pembentukan konsep, aplikasi dan penutup (Hanson, 2005). Tahap-tahap tersebut menekankan pada proses berpikir kritis yang berorientasi pada siswa (Sanjaya, 2006).

Laboratorium virtual merupakan bentuk simulasi dari laboratorium konvensional (Oidov, dkk., 2012). Laboratorium virtual memungkinkan kegiatan praktikum yang dilaksanakan menjadi lebih efisien dan memiliki pengaruh 
yang lebih baik dalam pemahaman konseptual siswa (Abou Faour dan Ayoubi, 2017). Laboratorium virtual disusun atas komponen-komponen kegiatan eksperimen berbasis inkuiri terbimbing berdasarkan Componens Of The Laboratory Investigation yaitu : judul, informasi, tujuan praktikum, alat dan bahan, prosedur kerja, prelab, pengamatan, aktivitas mikroskopik dan pertanyaan postlab (The College Board, 2013). Kegiatan eksperimen berbasis inkuiri terbimbing dapat meningkatkan minat siswa untuk belajar secara mandiri dan menemukan konsep (Andromeda, dkk., 2018). Selain itu, kegiatan praktikum juga dapat meningkatkan hasil belajar siswa secara kognitif (Andromeda, dkk., 2016). Laboratorium virtual memungkinkan siswa untuk melakukan eksperimen dan kegiatan-kegiatan yang secara nyata tidak dapat terlaksana (Hatherly, 2008).

Berdasarkan hasil observasi yang dilakukan di SMAS Adabiah 2 dan SMAN 15 Padang diperoleh data bahwa : 1) siswa telah terbiasa menggunakan bahan ajar dalam bentuk elektronik, 2) kesulitan yang dialami siswa pada materi hidrolisis garam terletak pada pemahaman konsep serta masih belajar dengan cara menghafal, 3) bahan ajar yang digunakan masih belum menarik bagi siswa, 4) tidak dapat terlaksananya kegiatan praktikum selama pembelajaran daring.

Penelitian yang dilakukan terkait dengan e-modul berbasis inkuiri terbimbing terintegrasi laboratorium virtual adalah penelitian yang dilakukan oleh Febriyandi dan Andromeda pada tahun 2019 yang menunjukkan validitas dan dan praktikalitas e-modul yang dikembangkan secara berturut-turut memiliki kevalidan sangat tinggi dengan rata-rata moment kappa 0,87 dan kepraktisan sangat tinggi dengan rata-rata moment kappa 0,88 pada uji praktikalitas guru dan kepraktisan sangat tinggi dengan rata-rata moment kappa 0,88 pada uji praktikalitas siswa (Febriyandi dan Andromeda, 2019).

Berdasarkan penjelasan diatas penulis tertarik untuk mengembangkan e-modul berbasis inkuiri terbimbing terintegrasi laboratorium virtual pada materi hidrolisis garam. Bahan ajar yang dikembangkan diharapkan mampu membuat siswa belajar secara mandiri sehingga mampu menunjang proses pembelajaran baik secara tatap muka maupun jarak jauh/daring.

\section{METODE PENELITIAN}

Penelitian ini menggunakan jenis penelitian pengembangan. Model pengembangan yang digunakan pada penelitian ini yaitu model pengembangan $4-D$ (four $-D$ ) yang terdiri atas 4 tahap yaitu tahap pendefinisian (define), tahap perancangan (design), tahap pengembangan (develop) dan tahap penyebaran (disseminate) (Trianto, 2010). Subjek penelitian terdiri atas tiga orang dosen kimia, empat orang guru kimia dan siswa kelas XII SMAS Adabiah 2 Padang.

Tahap pendefinisian (define) tersusun atas serangkaian langkah meliputi analisis ujung depan, analisis siswa, analisis tugas, analisis konsep serta analisis tujuan pembelajaran. Tahap ini bertujuan untuk menentukan dan mendefinisikan syarat-syarat yang harus terpenuhi dalam pembelajaran berdasarkan Kompetensi Dasar (KD) pada Kurikulum 2013 revisi.

Tahap perancangan (design) bertujuan untuk merancang bahan ajar dalam bentuk e-modul berbasis inkuiri terbimbing terintegrasi laboratorium virtual berdasarkan materi dan tujuan pembelajaran yang telah didefinisikan pada tahap pendefinisian (define). Pada tahap ini e-modul dirancang berdasarkan sintak pada model pembelajaran inkuiri terbimbing dan sesuai dengan komponen-komponen modul berdasarkan perpaduan Depdiknas (2008) dan Prastowo (2014).

Tahap pengembangan (develop) dilakukan untuk mengetahui kevalidan dan kepraktisan produk sehingga dihasilkan produk yang valid dan praktis melalui uji validitas dan uji praktikalitas. Uji validitas dilakukan oleh ahli yang terdiri atas dosen kimia dan guru. Indikator yang akan dinilai oleh ahli meliputi : 1) komponen isi mencakup kesesuaian dengan KD, kesesuaian dengan kebutuhan bahan ajar, kebenaran substansi materi pembelajaran dan manfaat untuk menambah wawasan, 2) komponen kebahasaan mencakup keterbacaan, kejelasan informasi, kesesuaian dengan kaidah bahasa Indonesia dan bahasa yang efektif, 3) komponen penyajian mencakup kejelasan tujuan yang akan dicapai, urutan penyajian, motivasi dan daya tarik, stimulus dan respon serta kelengkapan informasi, 4) komponen kegrafikan mencakup font, jenis serta ukuran huruf yang digunakan, lay out dan tata letak, ilustrasi, gambar dan foto serta desain tampilan.

E-modul yang telah diberikan penilaian oleh validator kemudian direvisi sesuai dengan saran-saran validator sehingga dihasilkan e- 
modul yang valid dan siap di uji coba pada uji praktikalitas. Uji praktikalitas dilakukan oleh guru kimia dan siswa SMA. Tahap pengembangan (develop) bertujuan untuk menghasilkan e-modul yang valid dan praktis. Tahap penyebaran (disseminate) tidak dilaksanakan karena keterbatasan waktu dan biaya.

Data yang diperoleh dianalisis dengan menggunakan indeks validitas yang diusulkan oleh Aiken (Kusmaidi dalam Retnawati, 2016). Angket penilaian uji validitas dan praktikalitas yang digunakan disusun berdasarkan skala Likert seperti pada Tabel 1 .

Tabel 1. Skala Likert (Retnawati, 2016)

\begin{tabular}{cc}
\hline Skala Likert & Penilaian \\
\hline 1 & Sangat tidak setuju \\
\hline 2 & Tidak setuju \\
\hline 3 & Netral \\
\hline 4 & Setuju \\
\hline 5 & Sangat setuju \\
\hline
\end{tabular}

Data hasil uji validitas dan praktikalitas yang diperoleh dianalisis dengan indeks validitas butir indeks Aiken's $V(\mathrm{~V})$ dirumuskan sebagai berikut :

$$
\begin{array}{r}
\mathrm{V}=\frac{\Sigma s}{\mathrm{n}(\mathrm{c}-1)} \\
s=r-l_{0}
\end{array}
$$

Keterangan:

$\mathrm{V}=$ Indeks kesepakatan rater

$1_{0}=$ Angka penilaian validitas yang terendah (dalam hal ini $=1$ )

$\mathrm{c}=$ Angka penilaian validitas yang tertinggi (dalam hal ini $=5$ )

$\mathrm{r}=$ Angka yang diberikan oleh seorang penilai

$\mathrm{n}=$ Jumlah rater

Tabel 2. Keputusan Berdasarkan Indeks Aiken's $V(\mathrm{~V})$ (Retnawati, 2016)

\begin{tabular}{cc}
\hline Interval & Kategori \\
\hline$\leq 0,4$ & Kurang \\
\hline $0,4<\mathrm{V} \leq 0,8$ & Sedang \\
\hline $0,8<\mathrm{V}$ & Valid \\
\hline
\end{tabular}

\section{Analisis Ujung Depan}

Analisis ujung depan dilakukan untuk mengetahui masalah yang dialami oleh guru dan siswa dalam pembelajaran kimia, khususnya mengenai bahan ajar yang digunakan dan materi hidrolisis garam. Berdasarkan hasil analisis kuisioner yang diberikan kepada guru dan siswa ditemukan beberapa masalah yang dialami oleh guru dan siswa yaitu bahan ajar yang digunakan masih belum menarik, materi hidrolisis garam masih dianggap sulit oleh siswa, siswa mengalami kesulitan dalam memahami konsep dan siswa masih belajar dengan cara mengahafal. Penyebaran kuisioner dilakukan di SMAN 15 Padang dan SMAS Adabiah 2 Padang.

\section{Analisis Siswa}

Analisis siswa dilakukan untuk mengetahui dan memahami karakteristik siswa dalam proses pembelajaran. Berdasarkan hasil analisis siswa diketahui bahwa model pembelajaran inkuiri terbimbing dapat diterapkan kedalam emodul untuk membantu siswa menemukan konsep. Selain itu, siswa cenderung menyukai bahan ajar yang terdapat animasi, gambar, video dan audio dan dengan tampilan yang menarik.

\section{Analisis Tugas}

Analisis tugas dilakukan untuk menentukan Indikator Pencapaian Kompetensi (IPK) dengan cara menganalisis Kompetensi Dasar (KD) 3.11 kelas XI pada kurikulum 2013 revisi.

\section{Analisis Konsep}

Analisis konsep dilakukan untuk menentukan konsep pokok yang dibutuhkan pada materi hidrolisis garam dengan cara mengidentifikasi konsep pokok yang diajarkan dan menyusunnya kedalam bentuk peta konsep.

\section{Analisis Tujuan Pembelajaran}

Berdasarkan hasil analisis kompetensi dasar (KD) dan indikator pencapaian kompetensi (IPK), maka dapat dirumuskan tujuan pembelajaran yang akan dicapai selama proses pembelajaran.

Tahap Perancangan (Design) 
Pada tahap perancangan dilakukan penyajian e-modul hidrolisis garam berbasis inkuiri terbimbing terintegrasi laboratorium virtual berdasarkan hasil analisis pada tahap pendefinisian (define). E-modul ini disusun atas komponenkomponen e-modul yang terdiri atas : cover, petunjuk penggunaan, kompetensi yang akan dicapai, lembar kegiatan, lembar kerja, lembar evaluasi, kunci jawaban dan daftar pustaka, emodul dirancang berdasarkan siklus pembelajaran inkuiri terbimbing. Perancangan e-modul menggunakan beberapa Software diantaranya : Microsoft Word 2010, Microsoft Publisher 2010, Unity3D, Microsoft PowerPoint 2010, Paint 3D, Adobe PhotShop dan Flip PDF Professional.

Aplikasi Microsoft Word 2010 digunakan untuk menyusun draft awal komponen-komponen penyusun e-modul yang kemudian disunting dengan menggunakan Microsoft Publisher 2010. Aplikasi Flip PDF Professional digunakan untuk mengubah tampilan e-modul kedalam bentuk digital sehingga tidak hanya memuat gambar dan teks saja namun dapat memuat video, animasi, serta siswa dapat menjawab pertanyaan pada modul secara langsung. Aplikasi Microsoft PowerPoint 2010 dan Paint 3D digunakan untuk membuat animasi pada e-modul. Aplikasi Unity $3 D$ dan Adobe Photoshop digunakan untuk membuat simulasi percobaan pada laboratorium virtual. Adapun tampilan rancangan e-modul dapat dilihat pada Gambar 1, 2 dan 3 serta rancangan laboratorium virtual dapat dilihat pada Gambar 4, 5, 6 dan 7 berikut ini.

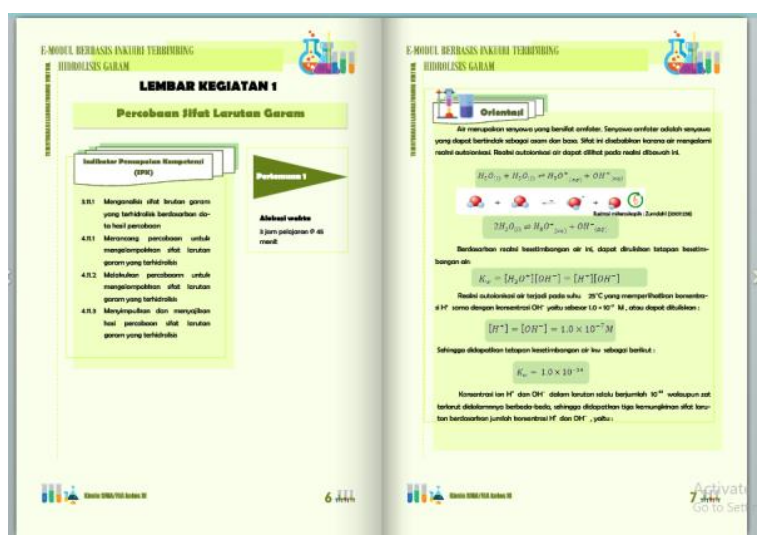

Gambar 1. Tampilan E-Modul pada Tahap Orientasi

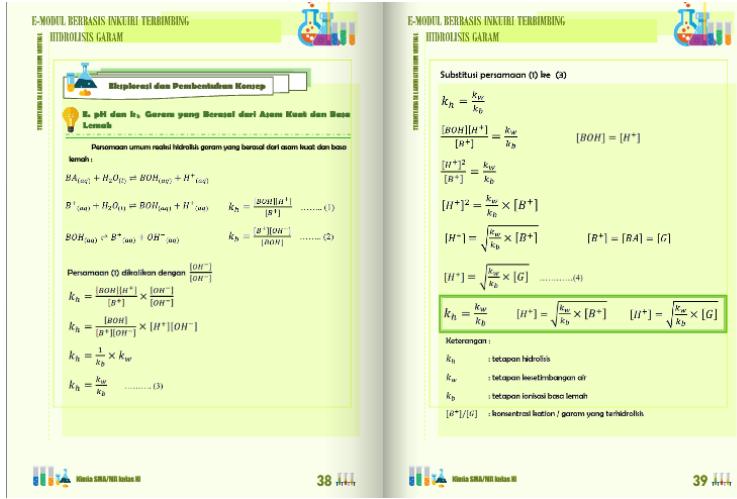

Gambar 2. Tampilan E-Modul pada Tahap Eksplorasi dan Pembentukan Konsep

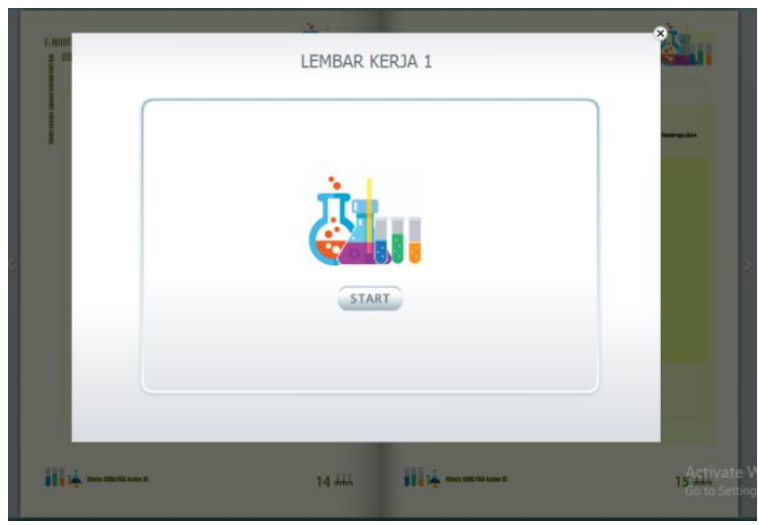

Gambar 3. Tampilan Lembar Kerja pada E-Modul Tahap Aplikasi

LABORATORIUM VIRTUAL Hidrolisis Garam

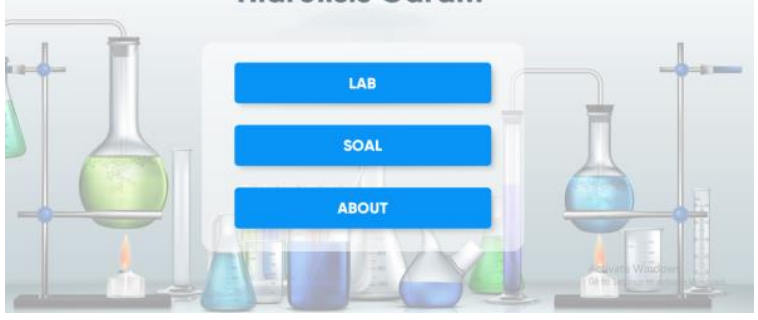

Gambar 4. Tampilan Judul dan Cover Laboratorium Virtual

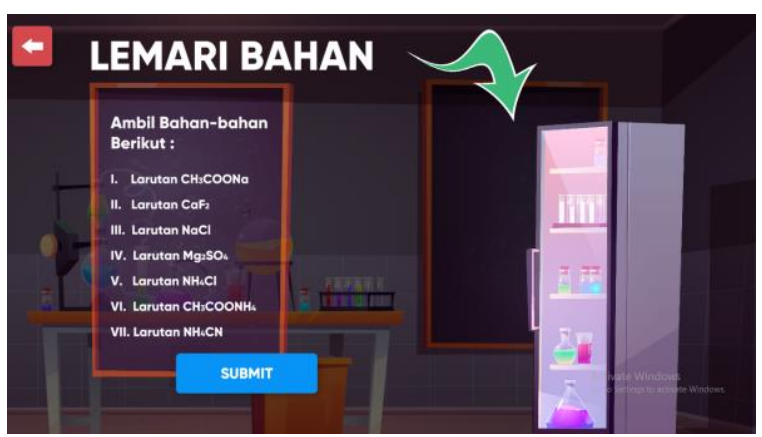

Gambar 5. Tampilan Alat dan Bahan Laboratorium Virtual 


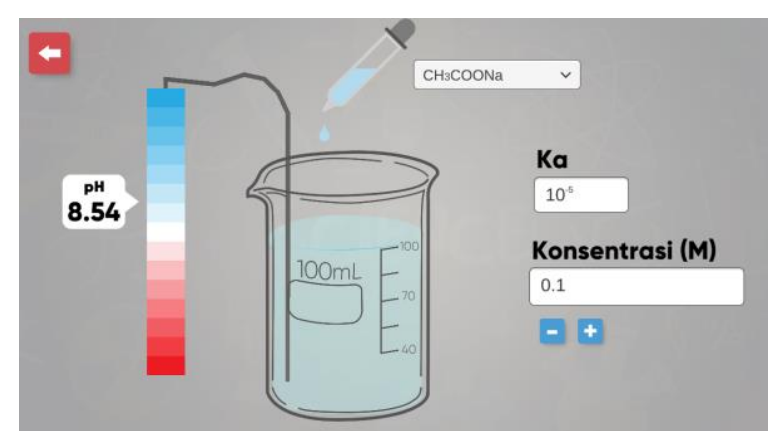

Gambar 6. Tampilan Simulasi Percobaan Laboratorium Virtual

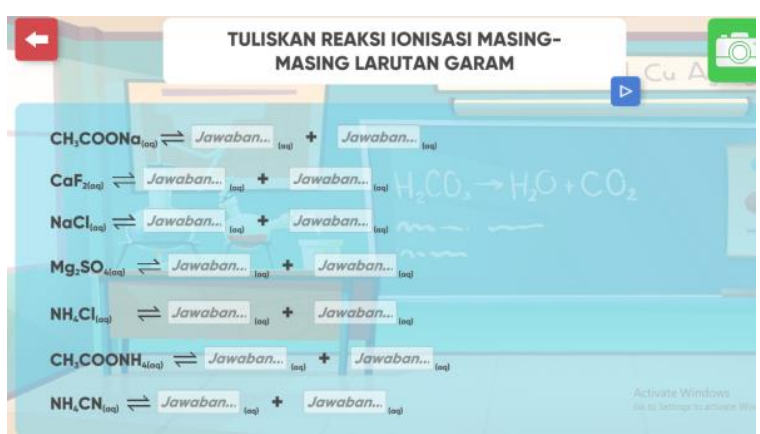

Gambar 7. Tampilan Pertanyaan Post-Lab Laboratorium Virtual

\section{Tahap Pengembangan (Develop)} Uji validitas

Uji validitas dilakukan untuk mengetahui penilaian dari rancangan produk atau bahan ajar yang dilakukan oleh ahli. Aspek penilaian pada uji validitas terdiri atas empat komponen, yaitu komponen isi, komponen kebahasaan, komponen penyajian, dan komponen kegrafikan (Depdiknas, 2008). Penilaian e-modul hidrolisis garam berbasis inkuiri terbimbing terintegrasi laboratorium virtual dilakukan oleh enam orang ahli yaitu 3 dosen kimia dan 3 guru kimia. Berdasarkan hasil analisis data penilaian e-modul menggunakan indeks Aiken's $V(\mathrm{~V})$ diperoleh hasil uji validitas yang terlihat seperti pada Tabel 4.

Tabel 3. Hasil Analisis Data Uji Validitas

\begin{tabular}{ccc}
\hline $\begin{array}{c}\text { Aspek yang } \\
\text { dinilai }\end{array}$ & $\mathbf{V}$ & Kategori \\
\hline Kelayakan Isi & 0,84 & Tinggi \\
\hline Penyajian & 0,84 & Tinggi \\
\hline Kebahasaan & 0,79 & Sedang \\
\hline Kegrafikan & 0,83 & Tinggi \\
\hline
\end{tabular}

Keterangan V = Indeks Aiken's $V$

Berdasarkan hasil analisis data penilaian komponen isi oleh validator, e-modul yang dikembangkan telah disusun berdasarkan Kompetensi Dasar 3.11 dan 4.11 kelas XI Kurikulum 2013 revisi. Penggunaan e-modul akan mudah dilaksanakan jika telah memuat implementasi dari Kompetensi Dasar, Indikator Pencapaian Kompetensi sera Tujuan Pembelajaran yang harus akan dicapai oleh peserta didik (Depdiknas, 2008). Rata-rata indeks Aiken's $V(\mathrm{~V})$ yang diperoleh sebesar 0,84 dengan kategori kevalidan tinggi.

Perolehan rata-rata indeks Aiken's $V(\mathrm{~V})$ penilaian komponen penyajian e-modul yaitu sebesar 0,84 dengan kategori kevalidan tinggi. Emodul hidrolisis garam berbasis inkuiri terbimbing terintegrasi laboratorium virtual yang dikembangkan telah disusun berdasarkan sintak pada model pembelajaran inkuiri terbimbing yaitu : 1) orientasi, pada tahap ini siswa dipersiapkan untuk memulai pembelajaran yaitu dengan pemberian motivasi, rasa ingin tahu dan melakukan persepsi, 2) eksplorasi dan pembentukan konsep, pada tahap ini siswa menganalisis model atau informasi yang diberikan serta siswa dipandu secara efektif untuk menemukan konsep melalui pertanyaan kunci/pertanyaan kritis, 3) aplikasi, pada tahap ini siswa dapat mengaplikasikan konsepkonsep yang telah dipahami dengan mengerjakan soal-soal yang berhubungan dengan masalah yang dianalisis sebelumnya, 4) penutup, pada tahap ini siswa melaporkan hasil yang ditemukan selama pembelajaran (Hanson, 2005). Pada tiap tahapan tersebut terdapat berbagai komponen yang dapat menarik perhatian siswa seperti gambar, video dan animasi serta materi-materi penunjang yang disajikan sehingga siswa mampu memahami materi dan menarik kesimpulan dari apa yang telah dipelajarinya. Soal-soal yang disajikan dalam e-modul telah disusun berdasarkan indikator dan tujuan pembelajaran. Selain itu siswa juga bisa mengukur sejauh mana pemahaman materi oleh siswa melalui feedback pada soalsoal pada lembar kerja dan lembar evaluasi.

Komponen kebahasaan memiliki rata-rata indeks Aiken's $V(\mathrm{~V})$ sebesar 0,79 dengan kategori kevalidan sedang. E-modul yang dikembangkan telah komunikatif, bahasa yang digunakan jelas serta konsisten dalam penggunaan simbol atau lambang. Penggunaan bahasa telah sesuai dengan kaidah Bahasa Indonesia sehingga siswa tidak mengalami kerancuan saat menggunakan e-modul. Bahasa yang digunakan pada e-modul sebaiknya merupakan kalimat yang sederhana dan efektif. Susunan ka- 
limat pada e-modul harus tepat sehingga membentuk kalimat yang komunikatif dan akrab bagi siswa. Penggunaan bahasa yang komunikatif dapat mempengaruhi minat siswa dalam belajar (Hamdani, 2011). E-Modul yang baik hendaknya bersifat user friendly (Depdiknas, 2008) dimana bahasa yang digunakan sederhana, jelas, menggunakan istilah umum serta mudah dimengerti (Daryanto, 2014).

Komponen kegrafikan memperoleh ratarata indeks Aiken's $V(\mathrm{~V})$ sebesar 0,83 dengan kategori kevalidan tinggi. Hal ini menunjukkan bahwa gambar, jenis dan ukuran huruf pada emodul dapat diamati dengan jelas, serta tata letak (lay out) dan desain tampilan e-modul menarik sehingga e-modul yang dikembangkan dapat bersahabat baik dengan peserta didik dan dapat membantu peserta didik memecahkan masalah. Penggunaan penyajian tampilan secara grafis dapat membantu dalam memecahkan masalah (Soon, 2005). Penggunaan jenis dan ukuran huruf yang konsisten juga dapat mempengaruhi kenyamanan siswa dalam menggunakan e-modul. Daya tarik siswa terhadap e-modul juga akan muncul jika tata letak dan desain yang digunakan menarik disertai dengan adanya unsur audio beserta animasi, hal ini juga akan meningkatkan motivasi, minat dan kreativitas peserta didik (Hamdani, 2011).

Secara keseluruhan rata-rata indeks $A i$ ken's $V(\mathrm{~V})$ dari penilaian masing-masing komponen e-modul hidrolisis garam berbasis inkuiri terbimbing terintegrasi laboratorium virtual sebesar 0,83 dengan kategori kevalidan tinggi. Hal ini menunjukkan bahwa e-modul hidrolisis garam yang dikembangkan telah valid dari segi isi maupun konstruk. Kevalidan bahan ajar dapat dilihat jika bahan ajar tersebut telah sesuai dengan indikator pada validitas isi dan validitas konstruk (Sudijono, 2011).

E-modul yang telah divalidasi oleh validator kemudian dilakukan beberapa perbaikan berdasarkan saran dari validator untuk menunjang kesempurnaan e-modul.

\section{Revisi}

Tahap revisi dilakukan untuk memperbaiki bagian e-modul hidrolisis garam berbasis inkuiri terbimbing terintegrasi laboratorium virtual yang dianggap masih harus dilakukan perbaikan oleh validator sebelum e-modul di uji coba pada tahap uji praktikalitas. Beberapa poin-poin perbaikan emodul oleh validator adalah : 1) memperbaiki pertanyaan pada pertanyaan kunci dengan pertanyaan yang lebih mudah dimengerti, 2) memperbaiki informasi pada tahap eksplorasi dan pembentukan konsep dengan informasi yang lebih relevan, 3) memperbaiki tampilan e-modul seperti warna latar belakang dan ukuran huruf pada persamaan kimia, 4) mengganti jenis pertanyaan pada laboratorium virtual untuk menghindari error dan 5) menambah pertanyaan pada lembar evaluasi dengan pertanyaan dalam bentuk essay.

Tabel 4. Perubahan E-Modul Setelah Revisi

\begin{tabular}{|c|c|c|c|}
\hline No. & Komponen & Sebelum revisi & Setelah revisi \\
\hline \multirow{4}{*}{\multicolumn{2}{|c|}{ 1. Penyajian }} & $\begin{array}{l}\text { Infromasi yang } \\
\text { diberikan belum } \\
\text { menstimulus } \\
\text { siswa }\end{array}$ & $\begin{array}{l}\text { Informasi yang } \\
\text { diperdalam diberi- } \\
\text { kan lebih }\end{array}$ \\
\hline & & $\begin{array}{l}\text { Pertanyaan dalam } \\
\text { bentuk isian }\end{array}$ & $\begin{array}{l}\text { Pertanyaan dalam } \\
\text { bentuk pilihan } \\
\text { ganda }\end{array}$ \\
\hline & & $\begin{array}{l}\text { Pertanyaan kunci } \\
\text { tersimpan di } \\
\text { penyimpanan lo- } \\
\text { kal komputer }\end{array}$ & $\begin{array}{l}\text { Mengintegrasikan } \\
\text { pertanyaan kunci } \\
\text { ke internet }\end{array}$ \\
\hline & & $\begin{array}{l}\text { Lembar evaluasi } \\
\text { terdiri dari } 25 \text { soal } \\
\text { pilihan ganda }\end{array}$ & $\begin{array}{l}\text { Menambah } 5 \text { soal } \\
\text { essay pada lembar } \\
\text { evaluasi }\end{array}$ \\
\hline & Kebahasaan & $\begin{array}{l}\text { Pertanyaan kunci } \\
\text { masih sulit dipa- } \\
\text { hami }\end{array}$ & $\begin{array}{lr}\text { Bahasa } & \text { yang } \\
\text { digunakan } & \text { pada } \\
\text { pertanyaan } & \text { kunci } \\
\text { disesuaikan } & \\
\text { kaidah basaha in- } \\
\text { donesia yang } \\
\text { benar }\end{array}$ \\
\hline 3. & Kegrafisan & $\begin{array}{l}\text { Rumus-rumus dan } \\
\text { persamaan kimia } \\
\text { sulit diamati }\end{array}$ & $\begin{array}{l}\text { Mengganti ukuran } \\
\text { huruf sehingga } \\
\text { lebih mudah dia- } \\
\text { mati }\end{array}$ \\
\hline
\end{tabular}

\section{Uji Praktikalitas}

Uji praktikalitas dilakukan untuk mengetahui bagaimana keterpakaian produk yang dikembangkan dilapangan. Uji praktikalitas dilakukan oleh guru kimia SMAS Adabiah $2 \mathrm{~Pa}-$ dang dan 15 orang siswa SMAS Adabiah $2 \mathrm{~Pa}-$ dang. Uji praktikalitas dilakukan dengan dua metode yaitu secara offline pada uji praktikalitas guru dan secara online pada uji praktikalitas siswa melalui google form. Guru kimia dan siswa diminta untuk mengisi angket praktikalitas yang berkaitan dengan kemudahan penggunaan emodul, kebahasaan e-modul, efisiensi waktu belajar menggunakan e-modul dan manfaat menggunakan e-modul, serta siswa diminta untuk mengerjakan soal-soal yang terdapat pada emodul. Hasil uji praktikalitas oleh guru dan siswa SMAS Adabiah 2 Padang dapat dilihat pada Tabel 5 dan 6. 
Tabel 5. Hasi Analisis Data Uji Praktikalitas Guru

\begin{tabular}{ccc}
\hline $\begin{array}{c}\text { Aspek yang } \\
\text { dinilai }\end{array}$ & $\mathbf{V}$ & Kategori \\
\hline $\begin{array}{c}\text { Kemudahan } \\
\text { penggunaan }\end{array}$ & 0,81 & Tinggi \\
\hline Kebahasaan & 0,81 & Tinggi \\
\hline Efisiensi waktu & 0,81 & Tinggi \\
\hline Kegrafikan & 0,83 & Tinggi \\
\hline Manfaat & 0,81 & Tinggi \\
\hline
\end{tabular}

Tabel 6. Hasi Analisis Data Uji Praktikalitas Siswa SMAS Adabiah 2 Padang

\begin{tabular}{ccc}
\hline $\begin{array}{c}\text { Aspek yang } \\
\text { dinilai }\end{array}$ & V & Kategori \\
\hline $\begin{array}{c}\text { Kemudahan } \\
\text { penggunaan }\end{array}$ & 0,81 & Tinggi \\
\hline Kebahasaan & 0,83 & Tinggi \\
\hline Efisiensi waktu & 0,82 & Tinggi \\
\hline Kegrafikan & 0,84 & Tinggi \\
\hline Manfaat & 0,79 & Sedang \\
\hline
\end{tabular}

Keterangan $\mathrm{V}=$ Indeks Aiken's $V(\mathrm{~V})$

Berdasarkan hasil analisis data uji praktikalitas menggunakan indeks Aiken's $V(\mathrm{~V})$ emodul yang dikembangkan telah praktis dengan kategori kepraktisan tinggi baik dari uji praktikalitas guru maupun uji praktikalitas siswa. Perolehan rata-rata indeks Aiken's $V(\mathrm{~V})$ uji praktikalitas guru dan siswa secara berturut-turut yaitu sebesar 0,81 dan 0,82 dengan kategori kepraktisan tinggi.

E-modul harus tersusun atas susunan yang sistematis sehingga dapat memenuhi kriteria self instructional yaitu meliputi tujuan pembelajaran yang jelas, memuat contoh dan ilustrasi yang mendukung kejelasan materi, menggunakan bahasa yang komunikatif, dan siswa dapat melakukan penilaian sendri (self assesment) dan terdapat umpan balik atas penilaian siswa (Daryanto, 2014). Berdasarkan hasil analisis penilaian komponen kemudahan penggunaan dan kebahasaan, e-modul yang dikembangkan telah memenuhi kriteria-kriteria tersebut dengan perolehan indeks Aiken's $V(\mathrm{~V})$ oleh guru sebesar 0,81 dan 0,81 dengan kategori kepraktisan tinggi serta perolehan indeks Aiken's $V(\mathrm{~V})$ oleh siswa sebesar 0,81 dan 0,83 dengan kategori kepraktisan tinggi.

Efisiensi waktu pembelajaran memperoleh rata-rata indeks Aiken's $V(\mathrm{~V})$ praktikalitas guru dan siswa sebesar 0,81 dan 0,82 dengan kategori kepraktisan tinggi. Penggunaan e-modul dapat meningkatkan efektifitas dan fleksibilatas pembelajaran (Suasarna dan Mahayukti, 2013) serta penggunaan laboratorium virtual dapat menghemat waktu karena lebih efisien (Saleh, dkk., 2009).

Kegrafikan e-modul memperoleh rata-rata indeks Aiken's $V(\mathrm{~V})$ uji praktikalitas guru dan siswa sebesar 0,83 dan 0,84 dengan kategori kepraktisan tinggi. Hal ini menunjukkan bahwa tampilan e-modul secara keseluruhan menarik bagi siswa sehingga dapat menarik minat siswa untuk belajar.

Manfaat e-modul memperoleh rata-rata indeks Aiken's $V(\mathrm{~V})$ uji praktikalitas guru dan siswa sebesar 0,81 dan 0,79 dengan kategori kepraktisan tinggi dan sedang. Hal ini menunjukkan bahwa e-modul dapat membantu siswa memahami konsep dengan baik dan belajar menemukan konsep sendiri. E-modul merupakan bentuk peng-implementasian sumber belajar mandiri sehingga dapat meningkatkan kompetensi atau pemahaman siswa secara koginitif (Sugianto, dkk., 2013).

\section{Analisis E-Modul Berbasis Inkuiri Terbimbing Terintegrasi Laboratorium Virtual}

E-Modul hidrolisis garam ini menggunakan siklus/sintak pada model pembelajaran inkuiri terbimbing yang terintegrasi dengan laboratorium virtual untuk meningkatkan minat belajar siswa. Penerapan laboratorium virtual mampu membuat peserta didik aktif dalam pembelajaran karena tampilan simulasi laboratorium virtual yang menarik dan mudah digunakan dapat menarik minat siswa (Swandi, dkk., 2014).

E-modul yang disusun berdasarkan sintak pada model pembelajaran inkuiri terbimbing ini terdiri atas tahap orientasi, eksplorasi dan pembentukan konsep, aplikasi serta penutup (Hanson, 2005). Pada tahap orientasi siswa diberikan gambaran mengenai materi yang akan dipelajari, didalamnya terdapat Indikator Pencapaian Kompetensi (IPK) yang harus dicapai siswa, materi pendukung, serta materi yang harus dipahami siswa sebelum melanjutkan ketahap berikutnya yaitu tahap eksplorasi dan pembentukan konsep.

Tahap eksploasi dan pembentukan konsep tersusun atas model dan informasi serta pertanyaan kunci. Model atau informasi dapat berupa diagram, grafik, tabel data, persamaan, eksperimen, laboratorium atau kombinasi lainnya (Hanson, 2005). Pada e-modul ini model-model yang digunakan berupa animasi, laboratorium virtual, dan persamaan. Selanjutnya setiap konsep yang 
terdapat pada model-model tersebut dipandu dengan pertanyaan kunci/pertanyaan kritis (crtical thinking question) (Hanson, 2006). Berdasarkan hasil analisis jawaban siswa pada e-modul siswa mampu menjawab pertanyaan pada pertanyaan kunci dengan persentase $90 \%$. Hal ini berarti siswa telah mampu mengeksplorasi konsep pada model-model yang diberikan dipandu dengan pertanyaan kunci.

Laboratorium virtual yang termasuk keadalam tahap eksplorasi dan pembentukan konsep tersusun pertanyaan pre-lab, prosedur kerja, alat dan bahan, simulasi atau pengamatan, serta pertanyaan post-lab. Penggunaan laboratorium virtual dapat memotivasi siswa untuk belajar pelajaran kimia sesuai dengan penelitian yang dilakukan oleh Sumargo dan Yuanita (2014) yang melaporkan bahwa penggunaan laboratorium virtual dapat memotivasi siswa dalam belajar serta memudahkan siswa dalam menyelesaikan soal-soal yang diberikan oleh guru.

Pembelajaran dengan menggunakan laboratorium virtual memudahkan peserta didik dalam memahami materi, dan kegiatan praktikum dapat diulang sesuai kebutuhan peserta didik tanpa menghabiskan banyak bahan yang akan digunakan dalam kegiatan praktikum. Tatli \& Ayas (2010) menyatakan bahwa laboratorium virtual merupakan media alternatif untuk melakukan kegiatan praktikum secara mandiri. Penggunaan laboratorium virtual dapat meningkatkan pemahaman peserta didik terhadap materi yang disampaikan (Scheckler, 2003). Adanya laboratorium virtual dimaksudkan untuk menanamkan konsep yang meliputi persiapan dalam kegiatan praktikum yang akan dilakukan, tampilan laboratorium virtual untuk memvisualisasikan materi yang bersifat abstrak, dan evaluasi proses pembelajaran yang dilakukan (Putri, dkk., 2013).

Pengamatan yang melibatkan teknologi akan meningkatkan keterampilan berpikir siswa sehingga membentuk pola pikir yang lebih baik. Hal ini sesuai dengan yang diungkapkan oleh Kinnon (dalam Muderawan, 2011) yang menyatakan bahwa teknologi akan membantu mengembangkan semua jenis keterampilan berpikir mulai dari tingkat yang paling mendasar hingga tingkat keterampilan berpikir kritis.

Tahap aplikasi memberikan kesempatan kepada siswa untuk mengukur pemahaman siswa mengenai materi dan konsep yang sebelumnya telah dieksplorasi pada tahap ekspolorasi dan pembentukan. Hasil analisis jawaban siswa terhadap pertanyaan pada lembar kerja pada emodul diperoleh bahwa siswa telah mampu menjawab pertanyaan pada lembar kerja sebesar 94,8\% dan pertanyaan pada lembar evaluasi sebesar $90 \%$.

Berdasarkan hasil analisis jawaban siswa yang dapat dilihat pada Gambar 7, secara keseluruhan e-modul hidrolisis garam berbasis inkuiri terbimbing terintegrasi laboratorium virtual yang dihasilkan dapat meningkatkan minat belajar siswa dalam belajar secara mandiri dan menemukan konsep. Hal ini sesuai dengan pendapat Sugianto, dkk. (2013) yang menyatakan bahwa e-modul dapat diimplementasikan sebagai sumber belajar mandiri yang dapat membantu siswa dalam meningkatkan kompetensi atau pemahaman secara kognitif yang dimilikinya.

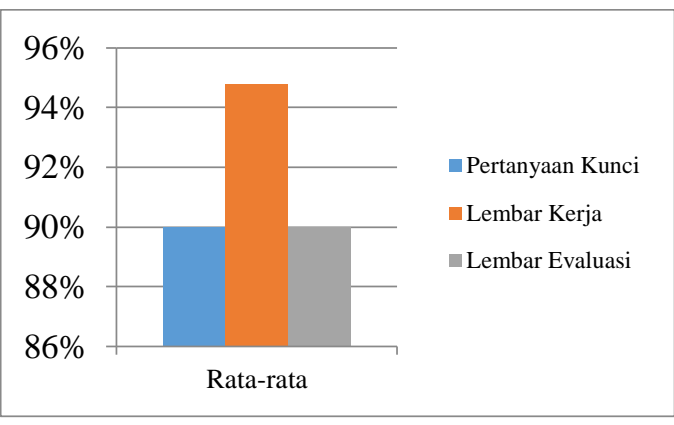

Gambar 8. Hasil Analisis Jawaban Siswa

\section{KESIMPULAN}

Berdasarkan penelitian yang telah dilakukan dapat disimpulkan bahwa e-modul hidrolisis garam berbasis inkuiri terbimbing terintegrasi laboratorium virtual untuk kelas XI SMA/MA dengan model pengembangan 4-D yang dihasilkan telah valid dan praktis.

\section{DAFTAR PUSTAKA}

Abou Faour, M., \& Ayoubi, Z. (2017). The effect of using virtual laboratory on grade 10 students' conceptual understanding and their attitudes towards physics. Journal Of Education In Science Environment And HEALTH, 4(1), 54-68.

Andromeda, A., Bahrizal, B., \& Ardina, Z. (2016). Efektifitas Kegiatan Praktikum Terintegrasi dalam Pembelajaran pada Materi Kesetimbangan Kimia Kelas XI SMA/MA. EKSAKTA, 1, 45-51. 
Andromeda, A., Lufri, L., Festiyed, F., Ellizar, E., Iryani, I., Guspatni, G., \& Fitri, L. (2018). Validity And Practicality of Experiment Integrated Guided InquiryBased Module on Topic of Colloidal Chemistry for Senior High School Learning. IOP Conference Series: Materials Science and Engineering, 335

Budiarti, S., Nuswowati, M., Cahyono, E. (2016). Guided Inquiry Berbantuan E-Modul untuk Meningkatkan Keterampilan Berpikir Kritis. Journal of Innovative Science Education, 5(2)

Daryanto. (2014). Pengembangan Perangkat Pembelajaran. Yogyakarta: PT Gava Media.

Depdiknas. (2008). Panduan Pengembangan Bahan Ajar. Jakarta: Departemen Pendidikan nasional.

Febriyandi, F., \& Andromeda, A. (2019). Pengembangan E-Modul Berbasis Inkuiri Terbimbing Terintegrasi Laboratorium Virtual Pada Materi Sistem Koloid Kelas XI SMA/MA. Edukimia, 1(3), 24-30.

Hamdani. (2011). Strategi Belajar Mengajar. Bandung : CV Pustaka

Hanson, D. M. (2005). Designing process-oriented guided-inquiry activities. Faculty Guidebook-A Comprehensive Tool for Improving Faculty Performance. 2nd ed. Pacific Crest.

Hatherly, P. A. The Virtual Laboratory And Interactivescreen Experiments. http://web.phys.ksu.edu/ diakses tanggal 20 Maret 2020

Kemendikbud. (2020). Panduan Penyelenggaraan Pembelajaran pada Tahun Ajaran dan Tahun Akademik Baru di Masa Covid-19. www.kemdikbud.go.id diakses 8 Agustus 2020

Muderawan, I.W. (2011). "Perkembangan

Teknologi Informasi dan Komunikasi dan Aplikasinya dalam Pembelajaran". Makalah disajikan dalam Seminar Nasional Optimalisasi Pemanfaatan Aplikasi IT dalam Dunia Pendidikan. Jurusan Pendidikan Teknik Informatika. Singaraja

Oidov, L., Tortogtokh, U., \& Purevdagva, E. (2012). Virtual laboratory for physics teaching. In International Conference on Management and Education Innovatio, IPEDR (Vol. 37, pp. 319-323).
Prastowo, Andi. (2014). Pengembangan Bahan Ajar Tematik. Jakarta: Kencana

Putri, A., Syakbaniah, \& Yulkifli. (2013).

Pengembangan virtual laboratory pada materi kinematika dengan analisis vektor dalam pembelajaran fisika kelas XI SMA. Pillar of Physics Education, 1

Retnawati, H. (2016). Analisis Kuantitatif Instrumen Penelitian. Yogyakarta: Parama Publishing.

Saleh, K. F., Mohamed, A. M., \& Madkour, H. (2009). Developing virtual laboratories environments for engineering education. International Journal of Arts and Sciences, $3(1)$

Sanjaya, Wina. (2006). Strategi Pembelajaran Berorientasi Standar Proses Pendidikan. Jakarta: Kencana Prenada Media Group.

Scheckler, R. K. (2003). Virtual Labs: A Subtitute for Traditional Labs?. International Journal Developmental Biology, 47(2)

Soon, Chong J.L. (2005). The Development and Evaluation of an E-Module for Pneumatics Technology. Journal of Instructional Technology (MOJIT), 2(3)

Suasarna dan Mahayukti. (2013). Pengembangan E-Modul Berorientasi Pemecahan Masalah untuk Meningkatkan Keterampilan Berpikir Kritis Mahasiswa . Jurnal Pendidikan Indonesia, 2(2)

Sudjiono, Anas. (2011). Pengantar Evaluasi Pendidikan. Jakarta: PT Raja Grafindo

Sugianto, D., Abdullah, A.G., Elvayanti, S., Muladi, Y. (2013). Modul Virtual: Multimedia Flipbook Dasar Teknik Digital. Jurnal INVOTEC, 9(2)

Sumargo, Eko dan Yuanita, Leny. (2014).

Penerapan Media Laboratorium

Virtual (PhET) pada Materi Laju

Reaksi dengan Model Pengajaran

Langsung. Unesa Journal of Chemical Education, 3(1)

Swandi, A., Hidayah, S. N., \& Irsan, L. (2014). Pengembangan Media Pembelajaran Laboratorium Virtual untuk Mengatasi Miskonsepsi pada Materi Fisika Inti di SMAN 1 
Binamu Jeneponto. Jurnal Fisika

Indonesia, 52(18)

Tatli, Z., \& Ayas, A. (2010). Virtual Laboratory Applications In Chemistry Education. Procedia Social and Behavioral Sciences, 938

Trianto. (2010). Model Pembelajaran Terpadu. Jakarta: Bumi Aksara

World Health Organization. (2020) . Timeline: WHO's COVID-19 response. https://www.who.int/ Diakses 8 Agustus 2020 